\begin{tabular}{r} 
Business and Economics Research Journal \\
Volume 8 Number 42017 \\
pp. $859-871$ \\
ISSN: $1309-2448$ \\
www.berjournal.com \\
\cline { 1 - 2 }
\end{tabular}

\title{
Küresel Raporlama Girişimi (GRI) Standartlarına Göre Seçilen Otellerin Sürdürülebilirlik Raporlarının Analizi ve Değerlendirilmesi
}

\author{
Vedat Ekergil $^{\text {a }}$ \\ Merve Özgür Göde ${ }^{b}$
}

\begin{abstract}
Öz: Son yıllarda işletmelerin ekonomik, sosyal ve çevresel sorumluluklarını yerine getirdiklerine yönelik bilgiyi toplumla paylaştıkları ve bazı ülkelerin bu raporların sunumunu yasal olarak zorunlu hale getirdikleri görülmektedir. İşletmeler, ekonomik, sosyal ve çevresel performanslarının sürdürülebilirlik düzeylerini izlemek amacıyla sürdürülebilirlik raporları hazırlamayı ve toplumla paylaşmayı tercih edebilmektedir. Diğer hizmet işletmeleriyle kıyaslandığında otel işletmeleri hem fiziksel hem de sosyal çevreyle yoğun ilişki içinde olduğundan sürdürülebilirlik raporlarının bilgi kullanııılarına sunulması önem arz etmektedir. Oteller tarafindan yayımlanan sürdürülebilirlik raporlarının gereken unsurları içerip içermediği, raporu inceleyenlerin işletmenin sürdürülebilirlik ile ilgili yeterli bilgiye ulaşıp ulaşmadığının ortaya çıkarılması bilgi kullanıcıları açısından önemlidir. Sürdürülebilirlik raporu hazırlayan işletmelerin bu raporları toplumla paylaşma istekliliğinin temelinde muhasebenin süreklilik, sosyal sorumluluk, önemlilik gibi varsayımları yatmaktadır. Çalışmanın amacı, uluslararası sürdürülebilirlik raporu standardına göre Türkiye'deki otellerin hazırladığı sürdürülebilirlik raporları incelenerek bu standartlar ve raporlar arasındaki benzer ve farklı yönleri ortaya çıkarmaktır. Bu amaç doğrultusunda Türkiye'deki oteller için uluslararası düzeyde önemi gittikçe artan sürdürülebilirlik raporlamasının hazırlanabilmesi için hangi unsurların gerekli olduğu da irdelenmektedir. Çalışmada nitel araştırma yaklaşımına dayalı doküman incelemesi ile veriler toplanmış ve verilerin çözümlenmesinde içerik analizi kullanılmıştır. Sonuç olarak Türkiye'deki otellerin sürdürülebilirlik raporlarını uluslararası standartlara uygun bir şekilde hazırlamadıkları tespit edilmiştir.
\end{abstract}

Anahtar Sözcükler: Sürdürülebilirlik, Sürdürülebilirlik Raporlaması, Kurumsal Sürdürülebilirlik, Otel İşletmeleri, Küresel Raporlama Girişimi-GRI

JEL Sınıflandırması: M40, M41, L83, Q56

\section{According to Global Reporting Initiative (GRI) Standards Analysis and Evaluation of Sustainability Reports of Selected Hotels}

\begin{abstract}
Recent years, it seems that businesses have shared the knowledge that businesses fulfill their economic, social and environmental responsibilities, and that some countries are legally obliged to present these reports. Businesses may prefer to prepare and share sustainability reports to monitor the sustainability levels of their economic, social and environmental performance. Compared to other service businesses, the environmental and social responsibilities of hotel business are more prevalent in their commercial activities. Since hotels are intimately involved in both the physical and social environment, it is important to present sustainability reports to information users. It is important for those who examine the sustainability reports to find out whether they have received sufficient information about sustainability and whether the sustainability reports published by the site contain the necessary elements. The main reason of sharing those reports for the enterprises which prepare sustainability report is based on the basic assumptions of accounting such as the continuity, social responsibility, materiality and so on. The aim of the study is to examine the sustainability reports prepared by the hotels in Turkey according to the global sustainability report standards and to reveal similar and different aspects between these standards and reports. For this purpose, it is also examined which elements are necessary for the sustainability reporting which is becoming increasingly important internationally for the Turkish hotels. In the study, data are collected through a document review based on the qualitative research approach and the content analysis is used in the analysis of it. As a result, it has been determined that the Turkish hotels do not prepare their sustainability reports according to international standards.
\end{abstract}

Keywords: Sustainability, Sustainability Report, Corporate Sustainability, Hotel Business, Global Sustainability Reports-GRI

JEL Classification: M40, M41, L83, Q56

${ }^{a}$ Assoc. Prof., PhD., Anadolu University, Open Education Faculty, Distance Education Department, Eskisehir, Turkiye, vekergil@anadolu.edu.tr

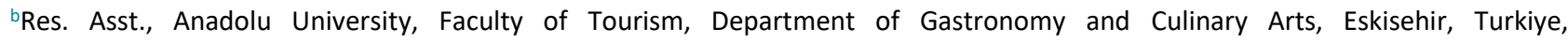
merveozgurgode@anadolu.edu.tr 


\section{Giriş}

Kurumsal sürdürülebilirlik, işletmelerin ekonomik, sosyal ve çevresel sorumluluklarını bir bütünlük içerisinde gerçekleştirmeyi, bu sorumluluk alanları arasında denge kurabilmeyi ve bu boyutlarda sürdürülebilir olmayı ifade etmektedir. İşletmelerin ve diğer kuruluşların faaliyetlerini sürdürebilmeleri ve yaşamlarını muhasebenin varsayımı olan süreklilik kavramıyla özdeştirebilmeleri için uzun vadeli kârlılğın sosyal adaletle ve çevreyle iç içe yürütülmesi gerekmektedir. İşletmenin tüm paydaşlarını (yönetim, yatırımcılar, çalışanlar, müşteriler vb.) bu sürece dâhil etmesi ve bilinçlendirmesi ile beklenen başarı elde edilebilir.

Sürdürülebilirlik raporlaması işletmelerin faaliyetlerini daha sürdürülebilir hale getirmek için hedef belirlemelerine, performanslarını ölçmelerine ve değişimleri yönetmelerine yardımcı olmaktadır. Sürdürülebilirlik raporu bir işletmenin çevre, toplum ve ekonomi üzerindeki olumlu veya olumsuz etkilerine ilişkin bildirimler iletmektedir. İşletmeler genellikle başarısını finansal tablolarla kanıtladıkları kâr büyüklükleriyle ölçmektedir. İşletmenin finansal tablolarında raporladığı kâr, işletmenin faaliyetlerinin sürdürülmesinde karşılaşabileceği sorunların ve aksaklıkların üstesinden gelmek amacıyla bilgi kullanıcılarına iletilmektedir. Ticari kâr, ortaklar, yatıımcılar, kreditörler ve rakiplere yönelik verilen bir mesajdır. İşletme, ortaklarına konulan sermayenin korunduğuna ve güvende olduğuna, yatırımcılara fonlarından elde edecekleri temettü payına, kreditörlere işletmeye verdikleri borçların geri ödenebileceğine ve rakiplere pazar içindeki duruma ve performansa ilişkin mesajlar ve garanti vermektedir. Mali kârla ise devletin beklemekte olduğu vergiye ulaşabileceği mesajı verilmektedir. İşletme dışına yönelik bu tür bilgiler verilirken, işletme içi bilgi kullanııısı olan yöneticiler de kârdan kendilerine pay çıkarmaktadır. Kâr bir başarıdır ve bunu gerçekleştiren ekibin ödüllendirilmesi gerekmektedir. Söz konusu bilgi kullanıcıları ise son derece vefasız dostlardır. Kârın devamlılığının sağlanmaması durumunda tüm bu bilgi kullanıcıları işletmeyi terk ederler. Kâr ise işletme hayatını sürdürdüğü sürece söz konusu olabilir. Görüldüğü gibi kâr büyüklüğü işletmenin gelecekte hayatını sürdürüp sürdüremeyeceğine ilişkin bir bilgi üretmemektedir.

İşletmenin karşılaştırılabilir finansal tablolarında kâr kaleminin olması, onun kişiliğinin sürekliliğini perçinlememektedir. Artık işletmeler verimli, etkin ve aynı zamanda sürekliliği sağlayabilmek için, finansal raporları kurumsal sürdürülebilirlik raporlarıyla desteklemesi gerekmektedir (Topcu ve Korkmaz, 2015: 3). Kurumsal sürdürülebilirlik ile işletmenin toplumun bir parçası olma başarısını da ölçmektedir ki, bu başarı finansal başarısını sağlayan temel unsurdur. Böylelikle işletmeler sürdürülebilirlik raporlaması ile soyut konuları somut hale getirerek, sürdürülebilirlik gelişimlerinin işletmenin faaliyetleri ve stratejisi üzerindeki etkilerinin anlaşılmasına ve yönetilmesine yardımcı olmaktadır.

\section{Kavramsal Çerçeve}

Çalışmada kavramsal çerçeve sürdürülebilir kalkınma, kurumsal sürdürülebilirlik ve sürdürülebilirlik raporlaması başlıklar altında incelenecektir.

\subsection{Sürdürülebilir Kalkınma ve Kurumsal Sürdürülebilirlik}

Sürdürülebilirlik ve sürdürülebilir kalkınma kavramlarının geniş bir çerçevede ve önemde değerlendirilmesi, 1987 yılında Londra'da düzenlenen Dünya Çevre ve Kalkınma Komisyonu'nda sunulan Brundtland Raporu ile gerçekleşmiştir. Brundtland Raporu, endüstri devrimi, hızlı sanayileşme ve ekonomik büyüme sonrası insanlığın karşı karşıya geldiği doğa ve çevre tahribatına dikkati çekmiş; büyüme, gelişme ve çevre korumanın bir arada gerçekleştirilebilmesinin mümkün olduğunu belirterek çevrenin, doğal kaynakların etkin bir şekilde korunması gerektiğini vurgulamıştır (WCDE, Our Common Future 1987: 54-55). Bir değişim süreci olarak algılanabilecek sürdürülebilir kalkınma; ekonomik, sosyal ve çevresel boyutları içermektedir. Sürdürülebilirliğin çevresel boyutunda yenilenebilir kaynak sistemlerinin istismarından kaçınarak, yenilenemeyen kaynaklardan ise yalnızca yatırımlarla yerine yeterince konulabilecek olanların tüketilmesi ifade edilmektedir. Ekonomik sürdürülebilirliğin sağlanabilmesi için ise mal ve hizmetlerin süregelen esaslara dayanarak üretilmesi; hükümet ve dış borçların yönetilebilirliğinin sürdürülmesi, tarımsal ve endüstriyel üretime zarar veren sektörel dengesizliklerden kaçınılması amaçlanmaktadır. Sosyal sürdürülebilirlik, insani 
gelişim ve yaşam standartları ile bağlantılıdır. Sosyal boyutla ise, adaleti ve toplumun bütün kesimlerinin karar verme sürecine katılımı öngörülmektedir (Holmberg ve Sandbrook, 1992).

Sürdürülebilir kalkınma çevrenin korunması ile ekonomik kalkınma kavramlarının bir arada değerlendirildiği ve var olan kaynakların en etkili kullanımına odaklanan yaklaşımı ifade etmektedir. Sürdürülebilir kalkınma esas itibariyle, ekoloji ile ekonomi arasında bir denge kurarak, doğal kaynakları bugünden tamamen tüketmeden, aynı dünyayı paylaşacağımız gelecek nesillerimizin ihtiyaçlarının karşılanmasına olanak verecek şekilde kalkınmayı sağlamak demektir. Bu bağlamda, sürdürülebilir bir çevre anlayışının oluşturulması için atıması gereken ilk adım; çevreyi ekonominin bir alt kümesi olarak gören ve sınırsız üretim-sınırsız tüketim-kâr maksimizasyonu üçgenindeki kalkınma kavramı anlayışının tümüyle reddedilmesidir (Torunoğlu, 2004:1). Sürdürülebilir kalkınma yaklaşımında;

- doğal kaynakların yönetimi,

- çevrenin korunması,

- gelecek nesillerin ihtiyaçları ve

- $\quad$ sosyal ve ekonomik politikalar

adı altında dört anahtar konu birlikte ele alınmaktadır (Alagöz, 2007:4).

Sürdürülebilir kalkınma ilkelerinin, işletme düzeyinde ele alınması literatürde kurumsal sürdürülebilirlik olarak ifade edilmektedir (Signitzer ve Prexl, 2007:2). Kurumsal sürdürülebilirlik, işletme faaliyetlerinin sosyal ve çevreye yönelik olumsuz etkilerini, olumlu ekonomik ve toplumsal etkileriyle dengelemeyi hedefleyen yeni bir yönetim anlayışı olarak tanımlanabilir (Pothong ve Ussahawanitchakit, 2011:1). Bu yaklaşım kurumsal büyüme ve kârlılığın sürdürülebilirlik için önemli olduğunu kabul ederken, işletmeleri sosyal adalet ve eşitlik, çevreyi koruma ve ekonomik gelişme gibi sürdürülebilir kalkınmayla yakından ilişkili toplumsal hedeflerin peşinden koşmaya zorlamaktadır (Wilson, 2003:1).

Kurumsal sürdürülebilirlik, işletmelerin ekonomik, sosyal ve çevresel sorumluluklarını bir bütünlük içerisinde gerçekleştirmesi ve bu sorumluluk alanları arasında denge kurabilmesi ve bu boyutlarda sürdürülebilir olmasını ifade etmektedir. Bu bağlamda kurumsal sürdürülebilirlik; ekonomik, sosyal ve çevresel boyutlardaki başarının bir ürünü niteliğindedir (Sarıkaya, Erdoğan ve Kara, 2010: 43).

Kurumsal sürdürülebilirlik, bir yandan yöneticilerin ve paydaşların şu anki mevcut ihtiyaçlarının karşılanmasına, öte yandan da işletmenin gelecekte ihtiyaç duyacağı beşeri ve doğal kaynakların korunması ve geliştirilmesine olanak sağlayan işletme stratejileri ve faaliyetlerinin benimsenmesi olarak tanımlanabilir (Roca ve Searcy, 2012:104). Konuyla ilgili diğer bir çalışmada Van Marrewijk (2003:102), kurumsal sürdürülebilirliği sosyal ve çevresel konuların işletme faaliyetlerine ve işletmenin paydaşlarla etkileşimine dâhil edilmesi şeklinde tanımlamıştır. Signitzer ve Prexl (2007:3) ise kurumsal sürdürülebilirliği ekonomik, sosyal ve çevresel hedef ve değerler arasında bir denge sağlamak için yapılan işletme çalışmalarının planlı ve stratejik yönetim sürecini tanımlayan göreceli bir kavram olarak nitelendirmişlerdir. Yapılan tanımlardan anlaşılacağı gibi kurumsal sürdürülebilirlik, işletme faaliyetlerinin sadece ekonomik boyutlarını değil, sosyal ve çevresel boyutlarını da göz önünde bulundurmayı gerekli kılmaktadır.

Kurumsal sürdürülebilirlik işletmelerin kurumsal ve yatırım stratejilerini en iyi biçimde uygulamalarını sağlayarak cari ve gelecekteki paydaşlarının bilgi ihtiyaçlarını karşılayan bir kavramdır (Artiach, Lee, Nelson ve Walker, 2010: 31). Bu kavram, işletmelerin finansal performans sonuçlarının yanı sıra ekonomik, yasal, etik ve gönüllü biçimde sosyal sorumlu birimler haline gelmeyi göz önünde bulundurmalarıyla bağlantılıdır (Bonilla-Priego, Font ve Olivares, 2014: 149).

Kurumsal sürdürülebilirlik kavramının önem kazanmasına yol açan bilgi kullanıcılarının beklentileri, işletmeleri ekonomik, çevresel ve sosyal boyutlarda sürdürülebilir bir yaklaşım benimsemelerini zorunlu kılmaktadır (Hardjono ve Klein, 2004: 100). Bu yaklaşım işletmelerin finansal başarılarının yanı sıra toplumsal ihtiyaçları da karşılayabilme ve çevresel duyarlılığın sürdürülebilirlik açısından önemi ve gerekliliğini savunmakta ve bir yükümlülük olarak görmektedir (Sarıkaya ve Kara, 2007: 225-226). 


\subsection{Sürdürülebilirlik Raporlaması}

Kurumsal sürdürülebilirlik için işletmelerin başarılarının sadece finansal raporlarına dayalı olarak değerlendirilmemesi gerekmektedir. İ̧letmenin sadece varlıkları ve kaynakları verimli bir şekilde kullanılması, korunması ve yönetilmesi ile elde edilen ekonomik kârlıık ile başarısını ölçmeye yönelik finansal raporlamanın yapılması, karar alıcıların beklentilerini karşılamakta yetersiz kalmaktadır. İşletme ve paydaşlar açısından finansal olmayan bilgilerin de raporlanması önemli bir gereklilik haline gelmiştir (Akarçay, 2014: 2). Finansal raporlama ile başlayan kurumsal raporlamanın gelişimi, 2020'li yıllara doğru detaylı ve çeşitlilik arz eden raporlarla devam etmektedir. Kurumsal raporlamanın gelişimi incelendiğinde, 2000'li yıllarda sürdürülebilirlik raporlamasını ve 2010 yılından sonra ise entegre raporlamayı kapsamına aldığı görülmektedir. (Karğın, Aracı ve Aktaş, 2013:31). Finansal raporlamanın bir uzantısı olan sürdürülebilirlik raporları işletmenin çevresel, ekonomik ve sosyal performansını açıklamada işletme raporlamasının kapsamını genişletmektedir (Clikeman, 2004). Başar ve Başar (2006) sosyal sorumluluk raporlamasını yıllık faaliyet raporlarında ya da ayrı raporlarda işletmelerin ekonomik, çevresel ve sosyal faaliyetlerinin boyutlarının gösterildiği işletme içi ve işletme dışı menfaat sahiplerine finansal ve finansal olmayan bilgi sunan raporlardır şeklinde tanımlamaktadır. Sürdürülebilirlik raporlaması ile işletmelerin sadece sattıkları ürünler, kârlılık oranları veya borsadaki hisselerinin değerleri değil, başta çalışanları olmak üzere, faaliyette bulunduğu topluma ve çevreye karşı ne kadar duyarlı olduğu her zamankinden daha önemli olmaktadır (Kağnıcıoğlu, 2009: 126).

Genellikle gönüllü olarak hazırlanan sürdürülebilirlik raporlarında yer alan bilgiler, finansal raporların aksine, daha çok nitelikseldir ve ölçülmesi daha zordur. Ayrıca finansal raporlar gibi yasal bir çerçevesi de bulunmamaktadır (Kağnıcıoğlu, 2009: 129). Sürdürülebilirlik raporları, merkezi Hollanda'da bulunan Küresel Raporlama Girişimi (Global Reporting Initiative - GRI) tarafindan çok kesin standart ve ölçümlere kavuşturulmuştur. 1999 yılından bu yana sürekli geliştirilen Sürdürülebilirlik Raporlama Kılavuzu (Sustainability Reporting Guidelines), 2015 yılında dördüncü kez güncellenerek G4 Standardı haline getirilmiştir (Gençoğlu ve Aytaç, 2016: 53). GRI Standartları, sürdürülebilirlik raporlaması için ilk küresel standartlardır. Bunlar modüler, birbiriyle ilişkili bir yapıya sahiptir ve bir dizi ekonomik, çevresel ve sosyal boyut için raporlama için küresel en iyi uygulamayı temsil etmektedir (www.globalreporting.org/standards). Yayımlanan G4 Standardı, 1 Temmuz 2018'den itibaren hazırlanan tüm sürdürülebilirlik raporlarında kullanılacaktır. İşletmeler belirli bilgileri rapor etmek için seçilen GRI Standartlarının tümünü veya bir kısmını kullanabilmektedir. Bu tarihten önce yayımlanan raporlarda G3 Standardı kullanılmaktadır. G4 Standardının, G3 Standardı ile kıyaslandığında daha kapsamlı ve genişletilmiş olduğu görülmektedir. Tablo 1'de G4 Standardının boyutları ve kapsamları verilmektedir.

Küresel Raporlama Girişimi (GRI) bütün dünyada kapsamlı sürdürülebilirlik raporlaması ile ilgili çerçevelerin oluşturulmasını sağlayan, bilgisayar ağı ortamında faaliyette bulunan bir kuruluştur. Sisteme işletmeler, sivil toplum kuruşları, insan kaynakları, akademik ve profesyonel kurum ve kuruluşlar katılabilir. Bu kurum ve kuruluşlar GRI'nın belirlediği kılavuza göre (G3 ve G4 Sürdürülebilirlik Raporlama Kılavuzu) hazırladıkları sürdürülebilirlik raporlarını çeşitli seviyelerde oluşturulan veri tabanına (Sustainability Disclosure Database) kaydederek onay alabilmektedirler (Karğın, Aracı ve Aktaş, 2013:33)

G4 Standardı sosyal boyut açısından G3 Standardına göre oldukça genişletilmiştir. G3 Standardında; "istihdam", "iş dünyası/yönetim ilişkileri", "eğitim-öğretim" ve "firsat eşitliliği" şeklinde dört başlık bulunurken, G4'te başlık sayısı 14'e çıkarılmaktadır. G3 Standardında çevresel boyutta "emisyonlar" ve "atıklar" başlıkları birbirinden ayrılmaktadır. "Ürünler ve servisler", "uygunluk", "ulaşım" ve "genel" başlıkları çıkartılarak yerine "çevresel uyum" ve "tedarikçi çevre değerlendirmesi" başlıklarına yer verilmektedir. Ekonomik boyutta ise var olan üç başlığa "satı alma uygulamaları", "yolsuzlukla mücadele" ve "rekabet" başıkları eklenmektedir. 
Tablo 1. G4 Standardının Boyutları ve Alt Başlıkları

\begin{tabular}{|c|c|c|}
\hline Ekonomik Boyut & Çevresel Boyut & Sosyal Boyut \\
\hline $\begin{array}{l}\text { - Ekonomik performans } \\
\text { - Pazar durumu } \\
\text { - Ekonomik etkiler } \\
\text { - Satın alma uygulamaları } \\
\text { - Yolsuzlukla mücadele } \\
\text { - Rekabet }\end{array}$ & $\begin{array}{l}\text { - Malzemeler } \\
\text { - Enerji } \\
\text { - Su } \\
\text { - Biyoçeşitlilik } \\
\text { - Emisyonlar } \\
\text { - Atık } \\
\text { - Çevresel uyum } \\
\text { - Tedarikçi çevre } \\
\text { değerlendirmesi }\end{array}$ & $\begin{array}{l}\text { - İstihdam } \\
\text { - İş dünyası/yönetim ilişkileri } \\
\text { - İş sağlığı ve güvenliği } \\
\text { - Eğitim ve öğretim } \\
\text { - Fırsat eşitliliği } \\
\text { - Ayrımcılığa uğramama } \\
\text { - Dernekler } \\
\text { - Çocuk işçiliği } \\
\text { - Zorla ve zorunlu çalışma } \\
\text { - Güvenlik uygulamaları } \\
\text { - İnsan hakları değerlendirmesi } \\
\text { - Yerel topluluklar } \\
\text { - Yerli halkların hakları } \\
\text { - Tedarikçi sosyal değerlendirmesi } \\
\text { - Kamu politikası } \\
\text { - Pazarlama } \\
\text { - Müşteri sağlığı ve güvenliği } \\
\text { - Müşteri gizliliği } \\
\text { - Sosyo-ekonomik uygunluk }\end{array}$ \\
\hline
\end{tabular}

Küresel Raporlama Girişimi (GRI) sürdürülebilirlik raporlarında bulunması gereken temel ilkeleri GRI 101: Kuruluş başlığı olarak yayımlamaktadır. GRI 101: Kuruluş, bir işletmenin ekonomik, çevresel ve / veya sosyal etkileri hakkında rapor vermek üzere GRI Standartlarını kullanmasının başlangıç noktasıdır. GRI 101 ilkeleri 3 ana grupta toplanmaktadır:

1. Raporun Esasları: Bu bölümde raporun içeriği ve raporun kalitesini tanımlayan esaslar bulunmaktadır. Bu esaslar bir işletmenin hangi bilgileri sürdürülebilirlik raporuna ekleyeceğine ve bilgilerin kalitesini nasıl sağlayacağına karar vermesine yardımcı olmaktadır.

2. Raporun Süreci: Sürdürülebilirlik raporlaması için GRI Standartlarını kullanmak için temel süreci açıklamaktadır. Bu bölümde raporlama esaslarının nasıl uygulanacağı ve raporlama için temel gereklilikleri içerir.

3. Kullanım Sartları: GRI Standartlarının kullanım kılavuzu ve standartları kullanan kuruluşlar için gerekli olan belirli kullanım bilgileri bu grupta verilmektedir.

Düzenli olarak ekonomik, çevresel ve sosyal performanslarını raporlayan işletmeler, işletmenin imajını güçlendireceklerine, çalışanlarının moralini ve motivasyonunu arttıracaklarına, nitelikli işgücünü çekebileceklerine ve kamuoyunun güvenini kazanabileceklerine inanmaktadırlar (Kağnıcıoğlu, 2009:129).

Finansal durumun raporlanmasının ötesinde sürdürülebilirlik raporlaması, işletmeler açısından aşağıda sıralanan birçok faydayı da beraberinde getirmektedir (Clikeman, 2004):

- Menfaat sahipleri (özellikle yatırımcılar, devlet vb.) için geçerli ve tutarlı bilgi sağlayarak şirketin şeffaflığını artırır.

- $\quad$ Uzun vadede pazar payını müşteri bağlılığını ve marka değerini arttırmaya katkıda bulunur ve bu durum şirketin piyasa değerini artırır.

- $\quad$ Çevresel ve sosyal riskleri daha iyi izlemek için yönetim sistemlerinin uygulanmasını teşvik eder ve kolaylaştırır.

- $\quad$ Çevresel ve sosyal konulardaki işletme değer ve ilkelerini göstermede yardımcı olur. 
Sürdürülebilirlik raporu, iç ve dış menfaat sahiplerinden sorumlu olabilen ve şirketin sürdürülebilir kalkınması doğrultusunda güvenilir olmasını sağlayan bir araçtır. Rapor, şirketin paydaşlarına pozitif veya negatif olan tüm katkıları içermelidir. Buna ek olarak, bu sürdürülebilirlik raporları şirketlerin stratejilerini, projelerini ve yönetim tarzlarını açık bir şekilde açıklamak zorundadır (Uzun Kocamış, 2016:44).

\section{Yöntem}

Yöntem bölümünde; araştırmanın modeli, amacı, kapsamı, süreci ve metodolojisi hakkında bilgi verilecektir.

\subsection{Araştırmanın Modeli}

Otel işletmelerinin sürdürülebilirlik raporlarının incelenmesini amaçlayan bu araştırma nitel araştırma yöntemi temel alınarak desenlenmiştir.

\subsection{Araştırmanın Amacı}

Çalışmanın amacı, uluslararası sürdürülebilirlik raporu standardına göre Türkiye'deki otellerin hazırladığı sürdürülebilirlik raporları incelemek ve GRI Standardı ile otellerin sürdürülebilirlik raporları arasındaki farklıııkların tespit edilip, analiz edilmesi ve sonuçların yorumlanmasıdır. Böylece Türkiye'deki otellerin hazırlayıp sunduğu sürdürülebilirlik raporlarının uluslararası standartlara uygunluğu test edilmiş olacaktir.

\subsection{Araştırmanın Kapsamı}

Araştırmada yer alan işletmeler, 2014-2017 yılları arasında Türkiye'de faaliyet gösteren otel işletmelerinden kendi resmî web sayfalarında sürdürülebilirlik raporlamasını yayımlayan 10 adet işletmeden oluşmaktadır. Türkiye'de otellerin hazırladığı sürdürülebilirlik raporları incelendiğinde, rapordaki ifadelerin bir şablondan çıkmış gibi olduğu görülmektedir. Bu nedenle internet sayfalarından ulaşılan raporların Türkiye'de otellerin sürdürülebilirlik raporlarını kapsadığı düşünülmektedir.

\subsection{Veri Toplama Süreci}

Araştırmada veri toplama aracı olarak otel işletmelerinin resmî web sayfalarında yayımladıkları sürdürülebilirlik raporlarından yararlanılmıştır. Otellerden e-posta vasıtasıyla da istenen rapor taleplerine ise yanıt alınamamıştır. Araştırma verileri, işletmelerin 2014-2017 döneminde yayımladıkları raporlar oluşturmaktadır. Otellerin sürdürülebilirlik raporlarının uluslararası standartlara uygunluğu Küresel Raporlama Girişimi (GRI)'nin yayımladığı G4 Sürdürülebilirlik Raporlama Kılavuzu esas alınarak gerçekleştirilmiştir. Sürdürülebilirlik raporları Nvivo 11 paket programı aracılığı ile otellerin internet adreslerinden alınmıştır.

\subsection{Araşttrmanın Metodolojisi}

Bu araştırma, nitel araştırma yaklaşımına dayalı doküman incelemesi ve dokümanlardan elde edilen verilerin içerik analizi yöntemiyle değerlendirilmesi şeklinde gerçekleştirilmiştir. Doküman incelenmesi, araştırılması hedeflenen olgu veya olgular hakkında bilgi içeren yazılı materyallerin analizini kapsar. Dokümanlar, nitel araştırmalarda etkili bir şekilde kullanılması gereken önemli kaynaklardır (Şener ve Samur, 2013: 514). Bir nitel araştırma yöntemi olan içerik analizi, bir metindeki değişkenleri ölçmek amacıyla sistematik, tarafsız ve araştırmacı tarafindan istenirse verileri sayısallaştırarak da yapılabilen analizdir (Bayram ve Yaylı, 2009: 15). Nitel analiz türlerinden biri olan içerik analizinde, mesaj değeri taşıyan her türlü veri, bulgu, araştırma amacı doğrultusunda analiz edilir ve yorumlanır. Birbirine benzeyen veriler, belirli kavramlar ve temalar çerçevesinde bir araya getirilir, okuyucunun anlayacağı biçimde düzenlenerek yorumlanır ve araştırmacı tarafindan gerekirse sayısallaştıılabilir (Başfirıncı, 2008: 53). 


\section{Bulgular}

Sürdürülebilirlik raporunda kaliteli bilgilerin sağlanabilmesi için; denge, karşılaştrılabilirlik, doğruluk, zamansal tutarlılık, netlik ve güvenilirlik ilkelerine uyulması gerekmektedir. Raporun hazırlanma sürecine ilişkin alınacak kararlar, bu ilkelerle tutarlı olmalıdır. Bilgi kalitesi, paydaşların yaratılan performansı gerçeğe uygun ve makul değerlendirmelerini ve uygun önlemleri alabilmelerini sağlamak bakımından önemlidir (www.globalreporting.org/resourcelibrary/Turkish-G4-Part-One.pdf).

Türkiye'de otellerin yayımlamış olduğu sürdürülebilir raporları herhangi bir düzenleyici kurumun talebi olmadığı için, raporlar belirli bir uluslararası standarttan uzak bir şekilde hazırlanmıştır. Oteller, hazırladıkları sürdürülebilirlik raporlarını bir pazarlama aracı olarak kullanmayı amaçlamaktadır. Bu nedenle sürdürülebilirlik raporlarındaki ifadeler birbirinden alınt alınarak hazırlanmaktadır.

Araşttrma amacı doğrultusunda otel işletmelerinin sürdürülebilirlik raporlarının incelenmesi suretiyle üç ana tema belirlenmiştir. Bu temalar; "çevre performansı", "ekonomik performans", "sosyal performans" şeklindedir. Tablo 2 'de üç ana tema için 718 kod tespit edilmektedir. Sürdürülebilirlik raporlarında ana temalara ilişkin kodların dağılımı incelendiğinde; \%60,86 ile "çevre performansı" kodların yarısından fazlasını almıştır. İşletme yönetiminin hazırladığı raporlar belirli bir amaç doğrultusunda hazırlanırlar. Araştırmaya konu olan otel işletmelerinin sürdürülebilirlik raporlarının rakip işletmeler karşısında bir üstünlük sağlama ve misafirlerine otelin diğer otellere göre daha çevreci bir yapıya sahip olduğunu kanıtlama çabası içinde olduğu görülmektedir. Kısaca rapor ile verilen mesaj "bizi seçin, çünkü biz toplumun geleceğine karşı görevlerimizi yerine getiriyoruz" şeklindedir. Aslında üst yönetimin sürdürülebilirlik raporunu yayımlanmasına izin vermesinin temel amacı, "otelin tutundurma faaliyetlerine katkı sağlamasıdır".

Tablo 2. Değerlendirilen Otellerin Sürdürülebilirlik Raporlarının Ana Temaları ve Dağııımı

\begin{tabular}{|l|l|r|r|}
\hline \multirow{2}{*}{ Temalar } & \multicolumn{2}{|c|}{ Kodlar } \\
\cline { 2 - 3 } & f & \multicolumn{1}{|c|}{$\%$} \\
\cline { 2 - 3 } Sosyal & 252 & $\% 35,10$ \\
Ekonomik & 29 & $\% 4,04$ \\
Çevre & 437 & $\% 60,86$ \\
\hline & & 718 & $\% 100,00$ \\
\hline
\end{tabular}

Tablo 3' de ana temaların her biri için alt temalar oluşturulmuş ve raporlardan elde edilen ilgili kodlar ile kodlanmıştır. Buna göre ana ve alt temaların dağılımı Tablo 3'de gösterilmektedir.

\subsection{Sosyal Boyut}

Işletmeler toplumun bir parçası olmadıkça, faaliyetlerini sürdürmeleri mümkün değildir. İşletme sahiplerinin yatırımı olan işletmelerden beklentileri olan kâr, sadece işletme sahiplerinin getirisi olarak görülmemelidir. Söz konusu kârın işletme paydaşlarıyla paylaşılması ve çıkar gruplarının tüm taraflarına adil bir bakış açısıyla yaklaşılmalıdır.

Muhasebe açısından da muhasebe uygulamalarının yürütülmesinde, finansal tabloların düzenlenmesi ve sunulmasında belli kişi ve grupların değil tüm toplumun çıkarlarının gözetilmesi ve dolayısıyla bilgi üretiminde gerçeğe uygun, dürüst ve tarafsız davranılması sosyal sorumluluk kavramını ifade etmektedir. 
Tablo 3. Değerlendirilen Otellerin Sürdürülebilirlik Raporlarının Alt Temaları ve Dağılımı

\begin{tabular}{|c|c|c|c|c|}
\hline & & & Kodlar & \\
\hline Temalar & Alt Temalar & Raporlar & $\mathbf{F}$ & $\%$ \\
\hline Sosyal & & 10 & 252 & $\% 35$ \\
\hline & İstihdam & 5 & 33 & $\% 13,1$ \\
\hline & İş dünyası-yönetim ilişkileri & 2 & 2 & $\% 0,8$ \\
\hline & İşçi sağlığı ve güvenliği & 7 & 19 & $\% 7,5$ \\
\hline & Eğitim ve öğretim & 7 & 33 & $\% 13,1$ \\
\hline & Fırsat eşitliği & 5 & 13 & $\% 5,2$ \\
\hline & Ayrımcılık & 3 & 4 & $\% 1,6$ \\
\hline & $\begin{array}{l}\text { Dernek kurma, toplu pazarlık } \\
\text { özgürlüğünü tehdit eden faaliyetler }\end{array}$ & 1 & 1 & $\% 0,4$ \\
\hline & Çocuk işçiliği & 1 & 1 & $\% 0,4$ \\
\hline & Zorla ve zorunlu çalıştırma & 1 & 1 & $\% 0,4$ \\
\hline & Yerel halkın hakları & 6 & 18 & $\% 7,1$ \\
\hline & İnsan hakları değerlendirmesi & 4 & 8 & $\% 3,2$ \\
\hline & Yerel topluluklar & 9 & 47 & $\% 18,7$ \\
\hline & Tedarikçi Sosyal Değerlendirmesi & 4 & 10 & $\% 4,0$ \\
\hline & Kamu politikası & 3 & 5 & $\% 2,0$ \\
\hline & Müşteri sağlığı ve güvenliği & 4 & 15 & $\% 6,0$ \\
\hline & Pazarlama & 6 & 21 & $\% 8,3$ \\
\hline & Müşteri gizliliği & 4 & 7 & $\% 2,8$ \\
\hline & Sosyo-ekonomik uygunluk & 7 & 14 & $\% 5,6$ \\
\hline Ekonomik & & 8 & 29 & $\% 4$ \\
\hline & Ekonomik performans & 3 & 10 & $\% 34,5 \%$ \\
\hline & Satınalma uygulamaları & 3 & 11 & $\% 37,9 \%$ \\
\hline & Pazardaki yeri ve konumu & 1 & 1 & $\% 3,4 \%$ \\
\hline & Dolaylı ekonomik etkiler & 6 & 7 & $\% 24,1 \%$ \\
\hline Çevre & & 10 & 437 & \%61 \\
\hline & Malzemeler & 8 & 25 & $\% 5,7$ \\
\hline & Enerji & 10 & 122 & $\% 27,9$ \\
\hline & Su & 10 & 59 & $\% 13,5$ \\
\hline & Biyoçeşitlilik & 8 & 64 & $\% 14,7$ \\
\hline & Emisyonlar & 8 & 21 & $\% 4,8$ \\
\hline & Atıklar & 10 & 124 & $\% 28,4$ \\
\hline & Çevresel uyum & 6 & 15 & $\% 3,4$ \\
\hline & Tedarikçi çevre değerlendirmesi & 3 & 7 & $\% 1,6$ \\
\hline
\end{tabular}

Kaynak: www.globalreporting.org/standards/gri-standards-download-center

Otel işletmeleri bulundukları doğa, yerel halk ve yerleşkenin bulunduğu koşulları yararlanarak hayatlarını sürdürmektedir. Bu nedenle varlıklarını sürdürebilmek için çevreye, yerel halka, tedarikçilerine ve çalışanlarına duyarlı olmak durumundadır. Sürdürülebilirlik raporlarına ulaşılabilen otel işletmelerinin raporlarının sosyal teması incelendiğinde; $\% 18,7^{\prime}$ si yerel topluluklar, $\% 13,1^{\prime} i$ istihdam, $\% 13,1^{\prime} i$ eğitim ve öğretim, \%8,3'ü pazarlama, $\% 7,5^{\prime} i$ iş sağlığı ve güvenliği, \%7,1'i yerel halkın hakları olarak öne çıkan alt temalardır. Bu alt temalar incelendiğinde GRI'nın belirttiği alt temaları kısmen karşıladığı görülmektedir. 
Örneğin sosyal temasının en fazla oranına sahip olan "yerel topluluklar" alt temasının temel içeriğini şu iki başlık oluşturmaktadır:

- Yerel topluluk katılımı, etki değerlendirmeleri ve kalkınma programları ile yapılan işlemler

- Yerel topluluklar üzerinde önemli ve potansiyel olumsuz etkilere neden olan işlemler

Bu iki başlıktan otellerin bulunduğu çevre ile yapmış olduğu etkinlikleri ve faaliyetleri içermektedir. Diğer bir çarpıcı örnekte ise "istihdam" alt teması için verilebilir. Standartta istihdam alt başlığı şunları içermektedir:

- Yeni çalışanların işe alımı ve çalışanların devri

- Geçici veya yarı zamanlı çalışanlara sağlanmayan tam zamanlı çalışanlara sağlanan faydalar

- Ebeveynlik izni

Otellerin sürdürülebilirlik raporlarında bu alt başıklardan sadece "yeni çalışanların işe alımında yerel halkın tercih edildiği”ne ilişkin ifadelere yer verildiği görülmüştür. Bu örnekleri çoğaltmak mümkündür.

Otellerin hazırlamış olduğu sürdürülebilirlik raporlarında; "sosyo-ekonomik uygunluk", "firsat eşitliği", "tedarikçi sosyal değerlendirmesi", "müşteri gizliliği", "kamu politikası" ve "insan hakları değerlendirmesi" alt temalara az da olsa değinildiği görülmektedir. Ancak raporlarda; "zorla ve zorunlu çalıştırma", "iş dünyası-yönetim ilişkileri", "dernek kurma", "çocuk iş̧̧iliği" ve "ayrımcılık" alt temalarına ilişkin olarak bir anlamda zorlama ile ilişkilendirme yapılmıştr. Sürdürülebilirlik raporlarında işletmenin durumunu, geleceğini ve sosyal çevresiyle olan uyumunu sergileyen bu unsurların raporlanması göz ardı edilmektedir. İşletmelerin ilgili taraflarına gösterdikleri saygı ve uyum çerçevesinde hayatlarını sürdürebilir oldukları bir gerçektir. Bu raporla bu durumların vurgulanması da bir gereklilik olarak görülmelidir.

\subsection{Ekonomik Boyut}

Kurumsal sürdürülebilirliğin sağlanmasında ekonomik boyut diğer boyutları birleştiren bir unsurdur. Sürdürülebilirliğin ekonomik boyutu, kuruluşun paydaşlarının ekonomik koşulları üzerindeki etkileri ve yerel, ulusal ve küresel seviyedeki ekonomik sistemlerle ilgilidir. İşletmenin varlıklarının ve kaynaklarının verimli bir şekilde kullanılması, korunması ve yönetilmesi ile elde edilen ekonomik kârlılığa ulaşılması durumunda sosyal ve çevre boyutlarının devamlığı sağlanacaktır. Bu açıdan işletmenin ekonomik performansı önem kazanmaktadır. Türkiye Muhasebe Standartları (TMS) hükümleri ile GRI'nın Standartları birlikte düşünüldüğünde benzer bir bakış açısının olduğu görülmektedir. GRI'nın "ekonomik performans" ve "satın alma uygulamaları" alt temalarında açıklanan işletmenin finansal boyuta ilişkin gelirleri ile giderlerinin tanımlanması, TMS'nin farklı standartlarında da tanımlanmaktadır (www.kgk.gov.tr/DynamicContentDetail/6538/TMS/TFRS-2017-Seti). Finansal yatırımlar, varlıklar satışları, işletme faaliyetleri, devlet yardımları ve teşvikler, emeklilik fayda planları, tanımlanmış katkı/fayda planları, iklim değişikliğine bağlı finansal sonuçlar ve diğer gelirler işletmenin yarattı̆ı direkt ekonomik değerlerdir. Ayrıca işletmenin gelirlerini yaratabilmesi için bazı giderlere katlanması da gerekmektedir. Bunlar; işletme maliyetleri, çalışanların ücretleri, hissedarlara yapılan ödemeler, devlete yapılan ödemeler, kamusal yatırımlar vb. şeklinde örneklendirilebilir. İşletmenin gelirleri ile giderleri arasındaki olumlu fark işletmenin ekonomik performansını yani kârlılı̆ını ortaya koymaktadır. Uluslararası alanda faaliyet gösteren otellerin hem finansal raporlarını hem de sürdürülebilirlik raporlarını standartlar kapsamında hazırlaması işletme içi ve dışı bilgi kullanıcılarının doğru, gerçeğe uygun ve zamanlı karar almalarına yardımcı olacaktır.

Satın alma uygulamaları aslında ekonomik performansın bir parçasıdır. Sürdürülebilirlik raporunun ekonomik temasının en büyük alt teması "satın alma uygulamaları"dır. İ̧̧letmenin tedarikçilerini ve tedarik sürecini verimli ve etkin bir şekilde yönetebilmesi için, tedarikçileri ile yaptığı satın alma sözleşmelerin yazılı, detaylı ve uygulanabilir olması gerekmektedir. Tedarikçilerin otel işletmesine yakın yerel işletmelerden seçilmesi ekonomik üstünlüklerin yanında çevre ve sosyal boyutlara da katkı sağlamaktadır. G4 işletmenin pazardaki yeri ve konumunu; çalışanların işe alımında asgari ücretin (pazar koşullarına göre) uygulanmasında cinsiyet farkının gözetilip gözetilmediği ve üst yöneticilerin ne kadarının yerel halktan olduğuna göre ölçmektedir. Otellerin sürdürülebilirlik raporlarında bu koşuları içeren doğrudan bir ifade bulunmamaktadır. 
Sadece bir otel raporunda "istihdam ettiğimiz personellerin bölge halkından olmasına dikkat ediyoruz" ifadesinden üst yönetimin de bölge halkında olabileceği çıkarsaması yapılmıştır.

Otel işletmelerin dolaylı ekonomik etkiler alt teması; desteklenen altyapı yatırımları ve hizmetleri, yabancı yatırımcıların pazara girmesi, sektörün ya da ekonominin verimliliğindeki değişmesi, tedarik zincirinin desteklenmesi, toplumsal veya çevresel koşulların iyileştirilmesi gibi önemli dolaylı ekonomik etkileri kapsamaktadır. Bu alt temada yabancı yatıımcıların otel işletmelerine olan ilgisi, otellerin markalaşma çabası ve pazarda acentelerin söz sahibi olması önemli dolaylı ekonomik etkiler olarak kabul edilmiştir.

Ekonomik boyutun "yolsuzlukla mücadele" ve "rekabet" alt temalarına ilişkin olarak otellerin sürdürülebilirlik raporlarında herhangi bir ifadeye yer verilmediği tespit edilmiştir. Bu alt temalar, özellikle Türkiye'deki otellere etik penceresini açmalarını sağlayacaktır.

\section{3. Çevre Boyutu}

Sürdürülebilirliğin çevresel boyutu, işletmenin kara, hava, su ve ekosistemler de dahil olmak üzere canlı ve cansız doğal sistemler üzerindeki etkisi ile ilgilenmektedir. Çevre temasının girdileri (enerji ve su gibi) ve çıktılar (emisyonlar, geri dönüşüme giden malzemeler ve atıklar gibi) ile ilgili unsurları içermektedir. Buna ek olarak, biyoçeşitlilik, lojistik ve ürün ve hizmetle ilgili etkilerin yanı sıra çevresel uyumluluk ve harcamalar yer almaktadır.

Otel işletmelerin sürdürülebilirlik raporlarda \%61 ile çevre en fazla yer verilen temadır. Otellerin sunduğu hizmetler karşılığında katlandığı maliyetler arasında enerji, su ve malzemeler en büyük tutarları oluşturmaktadır. Otel işletmelerinin sürdürülebilirlik raporlarında önemli olarak gördüğü bu kalemlere daha fazla yer verdiği görülmektedir. Çevre temasının \%28,4'ünde attklardan, \%27,9'unda enerjiden, $\% 13,5^{\prime}$ inde sudan bahsederek, çevre temasının $\% 69,8$ 'ini oluşturmaktadır. Standart tüketilen malzeme, enerji, suyun tüketiminin azaltımasına veya geri dönüşüm oranını artırarak artık ve atıkların azaltııması amaçlamaktadır.

Habitatın korunarak biyoçeşitliliğin devamlılığının sağlanması standartta çevre boyutunun önemli bir alt unsuru olarak karşımıza çıkmaktadır. Türkiye biyoçeşitliliği oldukça zengin bir ülkedir. Bitki, hayvan ve doğal oluşumların korunması turizm sektöründe sürdürülebilirlik açısından son derece önemlidir. Sürdürülebilirlik raporu incelenen otel işletmelerinin biyoçeşitlilikten anladığının "kedi evi yapmak", "kedilere mama vermek", "kuş evleri yapmak", "Caretta Caretta Kaplumbağalarını koruma altına almak" olduğu görülmektedir. Doğal hayatı korumaya yönelik olarak yeraltı sularının korunması, türleri azalan canlıların korunması, doğal değişim aralığı dışındaki ekolojik süreçlerdeki değişimlerin izlenmesi, geri döndürülemezliğe ilişkin önlemler alınması, vahşi hayata yaşam alanı açılması ve korunması gibi biyoçeşitlilik üzerinde doğrudan ve dolaylı etkilerin üzerinde ciddi bir şekilde çalışılması ve raporlanması gerekmektedir.

Otelin raporlama döneminde müşterilerine sunduğu hizmetler için kullandığı malzemelerden geri dönüşebilen ve geri dönüşemeyenlerinin belirlenmesi gerekmektedir. Geri dönüşüme uygun ya da uygun olmayan malzemelerin dönemler itibariyle karşılaştırabilmek için yüzdelerinin tespit edilmelidir.

Atıklar alt teması incelendiğinde, atıkların ayrıştrılması ve yok edilmesi ile atık miktarını azaltmaya yönelik önlemlere yönelik ifadeler yer almaktadır. Atık miktarının azaltılmasında genellikle işletme yönetiminin önlem aldığı görülmektedir. Bunun yanında işletme yönetimi; çalışanlarına atık konusunda eğitim verirken, misafirlerini ise atıkların ayrıştrılması ve geri dönüşüm programına katılmaya teşvik etmektedir.

\section{Sonuç}

Insan ihtiyaçları sonsuzdur. İtiyaçları karşılamayı talep edenler ise işletmelerdir. İşletmeler insanların ihtiyaçları karşılama karşılığında kendilerine toplumda bir yer verilmesini istemektedir. İşletmeler toplumda faaliyetlerini sürdürürken girişimcilerinden bağımsız bir tüzel kişiliğe sahip olurlar. Bu sayede hayatlarını girişimcilerinin hayatları ile sınırlandırmak zorunda kalmazlar. Muhasebede işletmelerin hayatları sonsuz bir süre olarak tanımlanmaktadır. Toplum içindeki görevlerini yerine getirdikleri sürece hayatta kalmalarında bir engel bulunmamaktadır. Hayatlarını sürdürebilmelerinin diğer bir koşulu ise girişimcilerinin kendisine sağlamış olduğu ve geri ödemesini talep etmemekle birlikte toplumdaki ihtiyaç sahiplerinden sağladığı kârdan 
girişimcisine pay vermesidir. İşletmeleri bu bakış açısıyla bal yapan bir arıya benzetmek mümkündür. Yaptı̆̆ balı hem hayatta kalmak için hem de insanlarla paylaşmak için yapmaktadır. Ancak arı balını yaparak topluma fayda sağlarken çevresine zarar vermemektedir. Doğal hayat korumaktadır. Ekonomik katma değer yaratmaktadır.

Her işletme gibi otel işletmeleri de hayatlarını sürdürme çabası içindedir. Hizmet sektöründe faaliyet gösteren oteller, toplumun ihtiyaçlarını karşılarken aynı zamanda toplumun kıt kaynaklarını en verimli şekilde kullanmak yerine kıt kaynakları en bonkör şekilde kullanarak müşterilerini memnun etme çabası içindedir. Bu çaba aşırı enerji, su, atık, artıkları ve israfi da beraberinde getirmektedir. Müşterilerini memnun ederken çevreye de zarar verebilmektedir. Bu ise aslında bir gökdelenin temelini kazmak gibidir. Bu önemli bir çelişkiyi ve çatışmayı da beraberinde getirmektedir. Deniz, hava, su, gürültü kirliliği ile cennet gibi bir ortamın cehenneme dönüşmesine ve müşteri memnuniyetinden müşteri memnuniyetsizliğine giden yolun açılmasına neden olabilmektedir. Tüm bunlar otel işletmeleri için yaşam mücadelesi içinde sürdürülebilirliğin ne kadar önemli olduğunu ortaya koymaktadır.

- $\quad$ Otel işletmeleri web sayfasını genellikle yatırımcılardan ziyade hizmet sunacağı müşterilerine yönelik hazırlandığı görülmektedir. Kamuyu bilgilendirmek amacıyla hazırlanan finansal raporlara bile ulaşmak neredeyse mümkün değildir. Sürdürülebilirlik raporları benzer bir amaç doğrultusunda hazırlanmaktadır. Raporlar belirli bir şablonun doldurulması olarak algılanmakta ve incelenen raporlarda temel ifadelerin aynı olduğu görülmektedir. Pazarlama, belirli belgelerin alınması, sürü psikoloji veya sektörün gerektirdiği bir zorunluluğa dayalı olarak sürdürülebilirlik raporu hazırlandığı görülmektedir.

- $\quad$ Otel işletmelerinin kurumsal sürdürülebilirlik raporunun işletmenin çevre, sosyal ve ekonomik boyutlarını göstermeye çalışmaktan ziyade, işletmenin tanıtılması, reklamı, müşteri memnuniyeti puanının artırılmasına yönelik yapılan bir çalışma olarak görüldüğü belirlenmiştir.

- Kurumsal sürdürülebilirlik raporları çevre ve sosyal boyutlarının yanında ekonomik boyuta da sahiptir. Otel işletmelerinin hazırlamış olduğu sürdürülebilirlik raporlarında ekonomik boyut raporun düzenlendiği dönemden ziyade işletmenin yaptığı yatırımların anlatıldığı bir alan olarak ifade edilmektedir. Otelin ilk açılışında yer alan ısıtma ve soğutma sistemi her dönem hazırlanan raporda yer almaktadır. Bu ise yıllar itibariyle işletmenin sürdürülebilirliğindeki gelişmenin takip edilmesini engellemekte ve bilgi kullanıcılarına gerçeğe uygun olmayan bilginin aktarılmasına neden olmaktadır.

- Kurumsal sürdürülebilirlik raporları incelendiğinde genel olarak otel işletmesinin sürdürebilirliği için gerekli olumlu ifadelerin yer aldığı görülmektedir. Sürdürülebilirlikle ilgili yaşadığı sorunlarından ziyade alınan önlemlerin devamlılığı, süreçlerin ve tasarrufların iyileştirilmesine, insan hakları, çocuk işçi çalıştırmama, doğaya zararlı kimyasalların ortadan kaldırılmasına yönelik planlara yer verilmektedir.

- Sürdürülebilirlik raporlarındaki temalar içinde en fazla çevre boyutuna yer verildiği görülmektedir.

- $\quad$ Çevre ana temasında en fazla attklar $(\% 28,4)$, enerji $(\% 27,9)$, biyoçeşitlilik $(\% 14,7)$ ve su $(\% 13,5)$ alt temalarına ilişkin ifadeler yer almaktadır.

- Raporlarda çevre ana teması içinde en az ifade edilen alt tema "tedarikçi çevre değerlendirmesi"dir. Bu alt temada; çevresel koşulları yerine getiren yeni tedarikçilerle çalışılması, yenilerinin bulunması ve tedarik zincirinde çevreyi olumsuz etkileyen unsurlara önlemler alınmasına yönelik ifadelerin yer alması beklenmektedir.

- Sosyal teması sürdürülebilirlik raporlarında toplam içinde \%35’i oluşturmasına rağmen, Standartta belirtilen konu başlıklarının birçoğuna ilişkin bilgiyi içermemektedir. Sosyal tema; sponsorluk, bağış, yardım gibi parasal değerlerle gerçekleştirilen faaliyetler olarak görülmektedir. Bunun yanında çalışanların sosyal hakları, işçi sağlığı ve güvenliği, çocuk işçilerin çalıştırılmasının önlenmesi, ilişkili taraflarla olan ilişkiler, ayrımcılık, firsat eşitliği, insan hakları, müşteri bilgilerinin 
gizliliği gibi çok önemli konuların raporlarda yer almadığı görülmektedir. İşletmelerin gelecekten beklentilerinin ve toplumda kendisine bir yer bulduğunun kanıt olan sürdürülebilirlik raporlarının bu kadar önemli konuları içermemesi, raporu hazırlayanların tekdüzeliğini ve derinlikten uzaklığını göstermektedir.

- Sürdürülebilirlik raporunda en az ifadenin olduğu tema ekonomik boyuttur. Otel işletmeleri kamuya sunulması gereken finansal raporları toplumla paylaşmaktan kaçınırken, finansal olmayan bir raporda ekonomik değerleri içeren ifadelere gerektiği gibi yer verilmesi beklenemez.

- Raporlarda en fazla ekonomik performans ve satın alma uygulamaları alt temalarından bahsedilmektedir. Bunun yanında yolsuzlukla ilgili risklere ilişkin işlemler, mücadele politikaları ve prosedürler ile iç kontrol sisteminin geliştirilmesine yönelik unsurların otel işletmelerinin sürdürülebilirlik raporlarında yer almadığı belirlenmiştir.

- Ayrıca ekonomik temasında işletmelerin rakipleri ile yaptığı rekabette, rekabet karşıt davranış, anti-tröst ve tekel uygulamalara ilişkin yasal düzenlemelere uyma durumuna ilişkin bilgilere yer verilmemektedir.

\section{Kaynaklar}

Alagöz, M. (2007). Sürdürülebilir kalkınmada çevre faktörü: Teorik bir bakış. Uluslararası Hakemli Sosyal Bilimler EDergisi, Sayı: 11, https://asosindex.com/cache/articles/article-1423868342.pdf (Erişim Tarihi: 22.04.2017).

Akarçay, Ç. (2014). Sürdürülebilirlik muhasebesi standartları kurulu. Marmara Üniversitesi Öneri Dergisi, 11 (42), 1-11.

Argüden, Y. (2002). Kurumsal sosyal sorumluluk. İstanbul: ARGE Danışmanlık Yayınları, No:03.

Artiach, T., Lee, D., Nelson, D., \& Walker, J. (2010). The determinants of corporate sustainability performance. Accounting \& Finance, 50(1), 31-51.

Başfirıncı Ç. (2008). Bir Pazarlama iletişim medyası olarak web ortamında içerik analizi yapmanın güçlükleri ve olası çözüm önerileri. Yönetim Dergisi, 53.

Başar, A. B., \& Başar, M. (2006). Sosyal sorumluluk raporlaması ve Türkiye'deki durumu. Anadolu Üniversitesi Sosyal Bilimler Dergisi, 213-230.

Bayram, M., \& Yaylı, A. (2009). Otel web sitelerinin içerik analizi yöntemiyle değerlendirilmesi. Elektronik Sosyal Bilimler Dergisi, 88, 347-379.

Bonilla-Priego, M. J., Font, X., \& del Rosario Pacheco-Olivares, M. (2014). Corporate sustainability reporting index and baseline data for the cruise industry. Tourism Management, 44, 149-160.

Brutland Raporu. http://www.un-documents.net/our-common-future.pdf (Erişim Tarihi: 22.05.2017.)

Clikeman, P. M. (2004). Socially conscious corporation. Strategic Finance, (2), 23-27.

Gençoğlu, Ü., \& Aytaç, A. (2016). Kurumsal sürdürülebilirlik açısından entegre raporlamanın önemi ve BIST Uygulamaları. Journal of Accounting \& Finance, (72).

Hardjono, T., \& P. de Klein, (2004). Introduction on the European Corporate Sustainability Framework (ECSF). Journal of Business Ethics, (55), 99-113.

G4 Sürdürülebilirlik Raporlaması Kılavuzu: Raporlama illkeleri ve Standart Bildirimleri, https://www.globalreporting.org/resourcelibrary/Turkish-G4-Part-One.pdf (Erişim Tarihi:26.06.2017).

GRI Sürdürülebilirlik Raporlaması Standartları, https://www.globalreporting.org/standards (Erişim Tarihi: 26.07.2017).

Holmberg, J., \& Sandbrook, R. (1992). Sustainable development: What is to be done? Making development sustainable: Redefining institutions, policy, and economics. (Ed. J. Holmberg). International Institute for Environment and Development, 19-38, Washington, D. C: Island Press.

IIRC. (2011). Towards integrated reporting, communicating value in the 21st century, 1-30, http://integratedreporting.org/wp-content/uploads/2011/09/IR-Discussion-Paper 2011_spreads.pdf (Erişim Tarihi: 23.05.2017).

Kağnıcıoğlu, D. (2009). Sosyal Sorumluluk Raporlarında Çalışma ve İstihdam Göstergeleri. Sosyal Siyaset Konferansları Dergisi, (57): 125-165. 
Karğın, S., Araci, H., \& Aktaş, H. (2013). Entegre raporlama: Yeni bir raporlama perspektifi. Muhasebe ve Vergi Uygulamaları Dergisi (MUVU)/Journal of Accounting \& Taxation Studies (JATS), 6(1).

Kuşat, N. (2012). Sürdürülebilir işletmeler için kurumsal sürdürülebilirlik ve içsel unsurları. Afyon Kocatepe Üniversitesi iiBF Dergisi, 14(2), 227-242.

Pothong, O., \& Ussahawanitchakit, P. (2011). Sustainable accounting and firm survival: An empirical examination of Thai listed firms. Journal of Academy of Business and Economics, 11(3),1-28.

Roca, L. C., \& Searcy C. (2012). An analysis of indicators disclosed in corporate sustainability reports. Journal of Cleaner Production,(20),103-118.

Sarıkaya, M., \& Kara, F. Z. (2007). Sürdürülebilir kalkınmada işletmenin rolü: Kurumsal vatandaşlık. Yönetim ve Ekonomi Dergisi, 14(2), 221-233.

Sarıkaya, M., Erdoğan, M., \& Kara, F. Z. (2010). Internet ekonomisi ve kurumsal sürdürülebilirlik. Eskişehir Osmangazi Üniversitesi IiBF Dergisi, 5(2), 31-50.

Şener, E., \& Samur, M. (2013). Sağlığı geliştirici bir unsur olarak sosyal medya: Facebookta sağlık. Gümüşhane Üniversitesi Sağlık Bilimleri Dergisi, 2(4).

Signitzer, B., \& Prexl, A. (2007). Corporate sustainability communications: Aspects of theory and professionalization. Journal of Public Relations Research, 20(1), 1-19.

TMS/TFRS 2017 Seti http://www.kgk.gov.tr/DynamicContentDetail/6538/TMS/TFRS-2017-Seti (Erişim Tarihi: 26.07.2017).

Tokgöz, N., \& Önce, S. (2009). Şirket sürdürülebilirliği: Geleneksel yönetim anlayışına alternatif. Afyon Kocatepe Üniversitesi, i.i.B.F. Dergisi, 249- 275.

Topcu, M. K., \& Korkmaz, G. (2015). Entegre raporlama: Kavramsal bir inceleme. Dokuz Eylül Üniversitesi Iktisadi ve Idari Bilimler Dergisi, 1, 1-22.

Torunoglu, E .(2004). Sürdürülebilir kalkınma paradigması üzerine ön notlar, TÜBiTAK Vizyon 2023 Panel İçin Notlar, https://www.tubitak.gov.tr/tubitak_content_files/vizyon 2023/csk/EK-16.pdf (Erişim Tarihi: 01.05.2017).

Uzun Kocamış, T. (2016). Sustainability reporting in Turkey: Analysis of companies in the BIST Sustainability Index. European Journal of Economics and Business Studies 6(1), 41-51.

Van Marrewijk, M. (2003). Concepts and definitions of CSR and corporate sustainability: Between agency and communion. Journal of Business Ethics, 44(2), 95-105.

Yanık, S., \& Türker, í. (2012). Sürdürülebilirlik ve sosyal sorumluluk raporlamasındaki gelişmeler (tümleşik raporlama). İstanbul Üniversitesi Siyasal Bilgiler Fakültesi Dergisi, (47).

Wilson, M. (2003). Corporate Sustainability: What is it and where does it come from?. Ivey Business Journal, (2), 1-5

WCDE (World Commission on Environment and Development), (1987). Our common future, Brundtland Report. Oxford: Oxford University Press. 54-55 